\title{
DECLARAÇÃo \\ DE INCONSTITUCIONALIDADE \\ DO ART. 1.790 DO CÓDIGO CIVIL \\ PELO SUPREMO TRIBUNAL FEDERAL \\ PRIMEIRA ANÁLISE SOBRE OS EFEITOS DA EQUIPARAÇÃO
}

\author{
Marília Pedroso Xavier* \\ Maici Barboza dos Santos Colombo**
}

Sumário: Introdução - 1. Tutela patrimonial da união estável e do casamento 1.1. Regime de bens - 1.2. Direitos sucessórios - 2. Efeitos do julgamento do Supremo Tribunal Federal: 2.1. Escolha do modelo jurídico de família; 2.2. Liberdade no âmbito sucessório - Conclusão - Referências.

* Doutora em Direito Civil pela Universidade de São Paulo (USP) e Mestre em Direito das Relações Sociais pelo Programa de Pós-Graduação em Direito da Universidade Federal do Paraná (UFPR). Professora dos cursos de graduação e pós-graduação da Faculdade de Direito da UFPR. Professora Adjunta do Núcleo de Prática Jurídica (NPJ). Coordenadora da Clínica Advocacia Disruptiva e do Observatório jurisprudencial em Direito de Família e Sucessões. Diretora do Departamento de Direito Civil do Instituto dos Advogados do Paraná. Conselheira Suplente da OAB/PR. Vice-Presidente da Comissão de Educação Jurídica da OAB/PR. Visiting Researcher no Max-Planck - Institut für auslandisches und internationales Privatrecht. Advogada, sócia do Leite, Xavier \& Pugliese Advogados Associados. Mediadora da Câmara de Mediação e Arbitragem da Associação Comercial do Paraná (Arbitac) e da Câmara de Arbitragem e Mediação da Federação das Indústrias do Paraná (Camfiep).

** Mestranda em Direito Civil e especialista em Direito Civil Constitucional pela Universidade do Estado do Rio de Janeiro (UERJ). Advogada. 


\section{INTRODUÇÃO}

A Constituição Federal de 1988 trouxe uma visão plural da família, reconhecendo expressamente a união estável como "entidade familiar" para efeito de proteção do Estado, sendo que deve a lei facilitar a sua conversão em casamento ${ }^{1}$. Esta inclusão foi salutar, pois as uniões afetivas não formalizadas pelo casamento foram por muito tempo marginalizadas no ordenamento jurídico brasileiro. A injustiça latente que decorria do desamparo patrimonial - sobretudo de companheiras, no caso de separação ou falecimento do companheiro - propulsionou o reconhecimento judicial de direitos à pessoa que mantinha um relacionamento informal, o que se deu de forma paulatina pela via jurisprudencial e com argumentos ligados à desigualdade de gêneros na relação conjugal. Neste sentido, ressalta-se que muitas decisões conferiram à companheira indenização pelos serviços domésticos prestados²

Após a promulgação da Constituição Federal, foram editadas as Leis ns. 8.971 de 1994 e 9.278 de 1996, ambas com a pretensão de regulamentar a proteção já conferida constitucionalmente à união estável. Por meio do art. $2^{\circ}$ da Lei $n$. 8.971/1994, deferiu-se ao companheiro o direito ao usufruto de um quarto ou metade dos bens do falecido, conforme existissem descendentes ou ascendentes, respectivamente, e garantiu-se a sua participação na sucessão do falecido, caso não houvesse descendentes e ascendentes. Enquanto vigente essa lei, o tratamento sucessório do cônjuge e do companheiro era semelhante, exceto apenas pelo direito real de habitação, conferido ao cônjuge e não ao companheiro, situação que foi alterada pela Lei n. 9.278/1996.

Durante esse período, portanto, cônjuge e companheiro eram tratados de forma isonômica quanto aos direitos hereditários e, se se considerar que o direito real de habitação previsto em prol do companheiro na lei de 1996 não se restringia pelo regime de bens ${ }^{3}$, poder-se-ia concluir até que o tratamento jurídico da união

1 Constituição Federal de 1988, art. 226. A família, base da sociedade, tem especial proteção do Estado.

$\$ 3^{\circ}$ Para efeito da proteção do Estado, é reconhecida a união estável entre o homem e a mulher como entidade familiar, devendo a lei facilitar sua conversão em casamento.

2 "A recorrente - casada religiosamente com José Moreira dos Santos, viúvo - residiu em companhia deste durante mais de 10 anos, prestando-lhe, até a morte, serviços domésticos; mas sem a condição de esposa, perante a lei civil, tenho por equitativa e justa a estipulação de uma remuneração em troca dos serviços utilizados pelo de cujus." Supremo Tribunal Federal, RE 15858, DJ 04/11/1950. Min. Rel. Barros Barreto.

3 Lei n. 9.278/1996, art. 7º, parágrafo único. Dissolvida a união estável por morte de um dos conviventes, o sobrevivente terá direito real de habitação, enquanto viver ou não constituir nova união ou casamento, relativamente ao imóvel destinado à residência da família. 
estável, nesse aspecto, era mais benéfico que o do cônjuge ${ }^{4}$, cujo direito real de habitação era condicionado pelo regime de bens ${ }^{5}$.

Contudo, o Código Civil de 2002 mudou o panorama ao ampliar significativamente o rol de direitos sucessórios do cônjuge, colocando-o, segundo o art. 1.829, como herdeiro concorrente com descendentes e ascendentes, nas primeira e segunda classes, respectivamente, e ocupando sozinho a terceira classe ${ }^{6}-$ com isso, afastando os parentes colaterais do cônjuge falecido -, além de alçá-lo à condição de herdeiro necessário ${ }^{7}$.

Em contrapartida, paradoxalmente, a situação sucessória do companheiro piorou, tendo este seus direitos regulamentados no polêmico art. $1.790^{8}$, dispositivo

4 "As leis ns. 8.971/94 e 9.278/96 regularam os direitos sucessórios do companheiro sobrevivente nos mesmos moldes da sucessão do cônjuge no Código Civil de 1916, salvo quanto à questão de os seus direitos hereditários independerem de suas relações patrimoniais, o que não acontecia com o cônjuge, razão pela qual a tendência era ampliar os direitos sucessórios do cônjuge independente do regime de bens, para uma equiparação ao disposto nas leis citadas." (NEVARES, Ana Luiza Maia. Como preservar a isonomia das entidades familiares na sucessão legal? In: TEPEDINO, Gustavo; TEIXEIRA, Ana Carolina Brochado; ALMEIDA, Vítor (Coord.). Da dogmática à efetividade do Direito Civil: Anais do Congresso Internacional de Direito Civil Constitucional - IV Congresso do IBDCIVIL. Belo Horizonte: Fórum, 2017, p. 240).

5 Código Civil de 1916 (revogado), art. 1.611, $\$ 2^{\circ}$ Ao cônjuge sobrevivente, casado sob o regime da comunhão universal, enquanto viver e permanecer viúvo será assegurado, sem prejuízo da participação que lhe caiba na herança, o direito real de habilitação relativamente ao imóvel destinado à residência da família, desde que seja o único bem daquela natureza a inventariar.

6 Código Civil, art. 1.829. A sucessão legítima defere-se na ordem seguinte:

I - aos descendentes, em concorrência com o cônjuge sobrevivente, salvo se casado este com o falecido no regime da comunhão universal, ou no da separação obrigatória de bens (art. 1.640, parágrafo único); ou se, no regime da comunhão parcial, o autor da herança não houver deixado bens particulares;

II - aos ascendentes, em concorrência com o cônjuge;

III - ao cônjuge sobrevivente;

IV - aos colaterais.

7 Código Civil, art. 1.845. São herdeiros necessários os descendentes, os ascendentes e o cônjuge.

8 Código Civil, art. 1.790. A companheira ou o companheiro participará da sucessão do outro, quanto aos bens adquiridos onerosamente na vigência da união estável, nas condições seguintes: I - se concorrer com filhos comuns, terá direito a uma quota equivalente à que por lei for atribuída ao filho;

II - se concorrer com descendentes só do autor da herança, tocar-lhe-á a metade do que couber a cada um daqueles;

III - se concorrer com outros parentes sucessíveis, terá direito a um terço da herança;

IV - não havendo parentes sucessíveis, terá direito à totalidade da herança. 
que previu a participação sucessória do sobrevivente somente quanto aos bens adquiridos onerosamente pelo casal na vigência da união estável, em concorrência com os descendentes ou outros parentes sucessíveis do falecido. E mais: se antes o companheiro herdava a totalidade dos bens na ausência de ascendentes e descendentes, pelo regramento do art. 1.790 do atual Código Civil a pessoa que mantinha união estável passou a herdar de forma concorrente com parentes colaterais do falecido, na proporção de apenas um terço da herança.

Dessa forma, o Código Civil de 2002 impôs um regime sucessório distinto daquele reservado aos casados, mudando o regramento até então vigente, em flagrante desfavor dos companheiros.

Diante das discussões acerca da constitucionalidade dessa distinção de tratamento legal das modalidades de família constituídas pelo casamento e pela união estável, o Supremo Tribunal Federal (STF) julgou os Recursos Extraordinários 646.721/RS e 878.694/MG, em sede de Repercussão Geral, fixando a seguinte tese: "No sistema constitucional vigente, é inconstitucional a distinção de regimes sucessórios entre cônjuges e companheiros, devendo ser aplicado, em ambos os casos, o regime estabelecido no art. 1.829 do CC/2002".

Nos casos julgados, o STF reconheceu a relevância social e jurídica da questão, razão pela qual foi admitido o julgamento em repercussão geral. Não poderia ser de outra forma, pois as uniōes não formalizadas pelo casamento cresceram significativamente no Brasil entre os anos de 2000 e $2010^{\circ}$, segundo resultados do Censo 2010, que detectou também serem mais frequentes em grupos de rendimentos menores. Portanto, as decisões sobre o tratamento jurídico sucessório da união estável atingem aproximadamente um terço dos brasileiros que mantêm algum relacionamento conjugal, o que ressalta os impactos sociais da decisão.

\section{TUTELA PATRIMONIAL DA UNIÃO ESTÁVEL E DO CASAMENTO}

\subsection{Regime de bens}

Como decorrência da proteção constitucional na condição de modalidade de família, o Código Civil de 2002 previu a aplicação à união estável da tutela patrimonial em vida conferida ao casamento, impondo aos companheiros, à semelhan-

9 Censo 2010: Uniões consensuais já representam mais de 1/3 dos casamentos e são mais frequentes nas classes de menor rendimento. Agência de Notícias IBGE. 17 out. 2012. Disponível em: <https://agenciadenoticias.ibge.gov. br/agencia-noticias/2013-agencia-de-noticias/ releases/14298-asi-censo-2010-unioes-consensuais-ja-representam-mais-de-1-3-dos-casamentos-e-sao-mais-frequentes-nas-classes-de-menor-rendimento.html> Acesso em: 24 abr. 2018. 
ça dos casados, o regime de bens da comunhão parcial, na ausência de acordo em sentido diverso ${ }^{10}$.

Observa-se, portanto, que a regulamentação patrimonial da união estável e do casamento, em vida, segundo o Código Civil de 2002, é similar, tratando-se, ambas, de núcleos familiares cujo patrimônio é regido pelas regras da comunhão parcial ou dos outros regimes de bens previstos no Código Civil, ou, ainda, de acordo com a vontade das partes.

A regulamentação anterior dada pela Lei n. 9.278/1996, embora tenha sido importante passo para a proteção do companheiro, não explicitou a aplicabilidade dos regimes de bens previstos para o casamento, mas sim, em dispositivo próprio, buscou garantir a atribuição patrimonial a cada um dos companheiros quanto aos bens onerosamente adquiridos na constância da união, presumindo-se o esforço comum e sendo possível a estipulação voluntária em contrário ${ }^{11}$. Antes disso, a Lei n. 8.971 de 1994 limitou-se a prever o direito aos alimentos e à sucessão causa mortis.

O Código de Processo Civil de 2015, por sua vez, colaborou na equiparação do tratamento jurídico do cônjuge e do companheiro, ao exigir expressamente a outorga conjugal para a propositura de ações que versem sobre direito real imobiliário também para aqueles que mantêm uniāo estável comprovada nos autos ${ }^{12}$.

10 Código Civil, art. 1.725. Na união estável, salvo contrato escrito entre os companheiros, aplica-se às relações patrimoniais, no que couber, o regime da comunhão parcial de bens.

11 Lei n. 9.278/1996: art. $5^{\circ}$ Os bens móveis e imóveis adquiridos por um ou por ambos os conviventes, na constância da união estável e a título oneroso, são considerados fruto do trabalho e da colaboração comum, passando a pertencer a ambos, em condomínio e em partes iguais, salvo estipulação contrária em contrato escrito.

12 Código de Processo Civil (Lei n. 11.105/2015), art. 73. O cônjuge necessitará do consentimento do outro para propor ação que verse sobre direito real imobiliário, salvo quando casados sob o regime de separação absoluta de bens.

$\$ 1^{\circ}$ Ambos os cônjuges serão necessariamente citados para a ação:

I - que verse sobre direito real imobiliário, salvo quando casados sob o regime de separação absoluta de bens;

II - resultante de fato que diga respeito a ambos os cônjuges ou de ato praticado por eles;

III - fundada em dívida contraída por um dos cônjuges a bem da família;

IV - que tenha por objeto o reconhecimento, a constituição ou a extinção de ônus sobre imóvel de um ou de ambos os cônjuges.

$\$ 2^{\circ}$ Nas ações possessórias, a participação do cônjuge do autor ou do réu somente é indispensável nas hipóteses de composse ou de ato por ambos praticado.

$\$ 3^{\circ}$ Aplica-se o disposto neste artigo à união estável comprovada nos autos. 
Por outro lado, o ponto de desvantagem da união estável situa-se na necessidade de outorga conjugal para a prática de atos materiais que possam comprometer o patrimônio ${ }^{13}$ comum ou individual, exceto no regime de separação total de bens. Esta regra, cuja finalidade é a proteção do patrimônio familiar, não comporta transposição automática para as situações convivenciais, pois a informalidade da união estável pode constituir óbice ao conhecimento público da necessidade de consentimento de companheiro para a prática de determinado ato jurídico. Neste sentido, em julgamento recente, o Superior Tribunal de Justiça, apesar de propugnar a exigência de vênia conjugal nos moldes exigidos pelo Código Civil no art. 1.647 para os companheiros, considerou que, em determinado caso concreto, em que não havia nenhuma informação na matrícula do imóvel quanto à existência de união estável, imperavam os interesses de terceiros de boa-fé que celebraram negócio jurídico com o companheiro, ainda que à revelia da companheira ${ }^{14}$. Esta

13 Art. 1.647. Ressalvado o disposto no art. 1.648, nenhum dos cônjuges pode, sem autorização do outro, exceto no regime da separação absoluta:

I - alienar ou gravar de ônus real os bens imóveis;

II - pleitear, como autor ou réu, acerca desses bens ou direitos;

III - prestar fiança ou aval;

IV - fazer doação, não sendo remuneratória, de bens comuns, ou dos que possam integrar futura meação.

Parágrafo único. São válidas as doações nupciais feitas aos filhos quando casarem ou estabelecerem economia separada.

14 RECURSO ESPECIAL. AÇÃO DE NULIDADE DE ESCRITURA PÚBLICA C.C. CANCELAMENTO DE REGISTRO DE IMÓVEIS. 1. ALIENAÇÃO DE BENS IMÓVEIS ADQUIRIDOS DURANTE A CONSTÂNCIA DA UNIÃO ESTÁVEL. ANUÊNCIA DO OUTRO CONVIVENTE. OBSERVÂNCIA. INTERPRETAÇÃO DOS ARTS. 1.647, I, E 1.725 DO CÓDIGO CIVIL. 2. NEGÓCIO JURÍDICO REALIZADO SEM A AUTORIZAÇÃO DE UM DOS COMPANHEIROS. NECESSIDADE DE PROTEÇÃO DO TERCEIRO DE BOA-FÉ EM RAZĀO DA INFORMALIDADE INERENTE AO INSTITUTO DA UNIÃO ESTÁVEL. 3. CASO CONCRETO. AUSÊNCIA DE CONTRATO DE CONVIVÊNCIA REGISTRADO EM CARTÓRIO, BEM COMO DE COMPROVAÇÃO DA MÁ-FÉ DOS ADQUIRENTES. MANUTENÇÃO DOS NEGÓCIOS JURÍDICOS QUE SE IMPÕE, ASSEGURANDO-SE, CONTUDO, À AUTORA O DIREITO DE PLEITEAR PERDAS E DANOS EM AÇÃO PRÓPRIA. 4. RECURSO ESPECIAL DESPROVIDO.

1. Revela-se indispensável a autorização de ambos os conviventes para alienação de bens imóveis adquiridos durante a constância da união estável, considerando o que preceitua o art. $5^{\circ}$ da Lei n. 9.278/1996, que estabelece que os referidos bens pertencem a ambos, em condomínio e em partes iguais, bem como em razão da aplicação das regras do regime de comunhão parcial de bens, dentre as quais se insere a da outorga conjugal, a teor do que dispóem os arts. 1.647, I, e 1.725, ambos do Código Civil, garantindo-se, assim, a proteção do patrimônio da 
situação evidencia que, apesar da tentativa de equiparação de direitos patrimoniais entre cônjuges e companheiros, a ausência de um ato formal e solene para a prova da união estável pode representar a inviabilidade do exercício de determinado direito no caso concreto, sem que isso decorra de uma redução da tutela em abstrato.

Contudo, em tese, os direitos patrimoniais assegurados ao companheiro em vida assemelham-se aos direitos patrimoniais do cônjuge, facultando-se aos companheiros a escolha do regime de bens que disciplinará as situações patrimoniais decorrentes da união estável, aplicando-se o regime de comunhão parcial supletivamente, caso não seja outra a vontade manifestada em acordo entre as partes, bem como, em regra, exigindo-se igualmente a vênia conjugal para atos que comprometam o patrimônio da família.

\subsection{Direitos sucessórios}

Se, por um lado, as tutelas patrimoniais do cônjuge e do companheiro, em vida, se assemelham, assegurada a escolha do regime de bens, o mesmo não ocorre com relação à tutela patrimonial sucessória.

Consigne-se, de início, que os artigos 1.790 , reservado à sucessão do companheiro, e 1.829, reservado à sucessão do cônjuge, padecem ambos de espinhosa e lacunosa técnica redacional, suscitando inúmeras dúvidas interpretativas ${ }^{15}$.

A situação do cônjuge, segundo o ordenamento jurídico vigente, é privilegiada: herda concorrentemente com descendentes e ascendentes e, na ausência destes, herda a totalidade da herança. Ademais, como herdeiro necessário, não pode ser

respectiva entidade familiar. 2. Não obstante a necessidade de outorga convivencial, diante das peculiaridades próprias do instituto da união estável, deve-se observar a necessidade de proteção do terceiro de boa-fé, porquanto, ao contrário do que ocorre no regime jurídico do casamento, em que se tem um ato formal (cartorário) e solene, o qual confere ampla publicidade acerca do estado civil dos contratantes, na união estável há preponderantemente uma informalidade no vínculo entre os conviventes, que não exige qualquer documento, caracterizando-se apenas pela convivência pública, contínua e duradoura. 3. Na hipótese dos autos, não havia registro imobiliário em que inscritos os imóveis objetos de alienação em relação à copropriedade ou à existência de união estável, tampouco qualquer prova de má-fé dos adquirentes dos bens, circunstância que impõe o reconhecimento da validade dos negócios jurídicos celebrados, a fim de proteger o terceiro de boa-fé, assegurando-se à autora/recorrente o direito de buscar as perdas e danos na ação de dissolução de união estável c.c partilha, a qual já foi, inclusive, ajuizada. 4. Recurso especial desprovido. (Superior Tribunal de Justiça, REsp 1.592.072/PR, 3a Turma, Min. Rel. Marco Aurélio Bellizze, j. 21 nov. 2017).

15 Mencione-se, a título exemplificativo, a falta de previsão sobre a filiação híbrida no art. 1.790 e a ausência de clareza no inciso I do art. 1.829. 
afastado por ato de vontade do falecido, exceto por razões graves que justifiquem a drástica medida ${ }^{16}$.

Pela literalidade do art. 1.790, por outro lado, na sucessão legítima o companheiro herda concorrentemente com descendentes e ascendentes do falecido em proporção bem inferior que o cônjuge e, além disso, passa a concorrer com os parentes colaterais do de cujus. Ou seja, em concorrência com irmãos, sobrinhos ou tios do falecido, o companheiro recebe apenas um terço da herança. Talvez seja essa uma das maiores e mais incoerentes distorções entre o regime sucessório do cônjuge e do companheiro: pressupor que o afeto do falecido com seus colaterais seja maior do que o afeto entre ele e sua companheira, enquanto, em situação semelhante no casamento, o cônjuge recebe a totalidade da herança e afasta os colaterais quando inexistentes ascendentes e descendentes. Sendo tanto o casamento quanto a união estável núcleos familiares de afeto, não parece consentâneo o privilégio dado ao parentesco colateral na sucessão da pessoa que mantinha união estável. Colaciona-se, a esse respeito, a indignação de Zeno Veloso:

$\mathrm{Na}$ sociedade contemporânea, já estão muito esgarçadas, quando não extintas, as relaçôes de afetividade entre parentes colaterais de $4^{\circ}$ grau (primos, tios-avôs, sobrinhos-netos). Em muitos casos, raramente se encontram. E o novo Código Civil brasileiro, que vai começar a vigorar no $3^{\circ}$ milênio, resolve que o companheiro sobrevivente, que formou uma família, manteve uma comunidade de vida com o falecido, só vai herdar, sozinho, se não existirem descendentes, ascendentes, nem colaterais até o $4^{\circ}$ grau do de cujus. Temos de convir: isto é demais! ${ }^{17}$

Por que a regra de afastamento dos colaterais, definida para os cônjuges, não foi reproduzida pelo legislador no tratamento jurídico-sucessório da união estável? Por que a união estável ensejaria menos afeto do que o casamento, a ponto de lhe ser relegada menor parcela do patrimônio do que aos parentes colaterais?

16 Código Civil, art. 1.961. Os herdeiros necessários podem ser privados de sua legítima, ou deserdados, em todos os casos em que podem ser excluídos da sucessão.

Art. 1.814. São excluídos da sucessão os herdeiros ou legatários:

I - que houverem sido autores, coautores ou partícipes de homicídio doloso, ou tentativa deste, contra a pessoa de cuja sucessão se tratar, seu cônjuge, companheiro, ascendente ou descendente; II - que houverem acusado caluniosamente em juízo o autor da herança ou incorrerem em crime contra a sua honra, ou de seu cônjuge ou companheiro;

III - que, por violência ou meios fraudulentos, inibirem ou obstarem o autor da herança de dispor livremente de seus bens por ato de última vontade.

17 VELOSO, Zeno. Direito Sucessório dos Companheiros. III Congresso Brasileiro de Direito de Familia. Out. 2001. Disponível em: <http://www.ibdfam.org.br/_img/congressos/anais/188. pdf.>. Acesso em: 27 abr. 2018. 
Foi esse um dos casos enfrentados pelo Supremo Tribunal Federal e que ensejou o julgamento da inconstitucionalidade do art. 1.790 do Código Civil: existentes três irmãos do falecido e inexistentes ascendentes e descendentes, a companheira receberia apenas um terço do patrimônio do de cujus, sendo que os outros dois terços, ou seja, a maior parte, seriam divididos entre os três irmãos do falecido. Por outro lado, se tivesse formalizado a união por meio do casamento, indubitavelmente todo o patrimônio do falecido seria transmitido à cônjuge.

Outra grande distorção entre os regimes sucessórios do cônjuge e do companheiro é a incidência apenas sobre os bens adquiridos onerosamente na vigência da união estável. Para o casamento, por outro lado, a lei leva em consideração o regime de bens, conduzindo à regra oposta: tanto maior será a proteção sucessória quanto menor for a proteção conferida pelo regime de bens eleito pelas partes ${ }^{18}$. Por essa razão, o art. 1.829, I, do Código Civil estipula que o cônjuge herdará somente os bens particulares no caso do regime de comunhão parcial de bens, pois sobre os bens comuns incide a meação; herdará os bens particulares no caso do regime de separação de ben ${ }^{19}$ e não herdará se casado no regime de comunhão universal, pois também recebe, nesse regime, a meação.

Apesar da questionável redação, extrai-se do inciso I do art. 1.829 que o regime de bens somente é relevante quando o cônjuge concorrer com os descendentes do falecido, situação em que herdará, em regra ${ }^{20}$, os bens particulares. Os bens comuns, por serem objeto de meação, não integram a herança do cônjuge.

18 "A tutela patrimonial do cônjuge no Direito brasileiro se traduz em dois aspectos distintos: o regime de bens do casamento e a sucessão causa mortis. Cuida-se de sistema integrado no âmbito do qual, em regra, na evolução legislativa brasileira, a maior proteção conferida no regime de bens se associa à diminuição na tutela no plano sucessório. Daí a necessidade de se interpretarem ambas as disciplinas jurídicas, de modo sistemático, para se alcançar plenamente a função promocional e protetiva do cônjuge pretendida pelo ordenamento" (TEPEDINO, Gustavo. Controvérsias sobre a sucessão do cônjuge e do companheiro. Pensar, Fortaleza, v. 17, n. 1, p. 138-160, jan./jun. 2012).

19 No regime de separação obrigatória, por força da literalidade do art. 1.829, I, o cônjuge não herdará os bens particulares. Contudo, a incomunicabilidade dos bens no regime legal de separação tem sido relativizada pelo Superior Tribunal de Justiça, com fundamento na Súmula 377 do Supremo Tribunal Federal, conforme se observa em julgado dessa Corte.

"Ementa: Separação judicial. Partilha. Bem imóvel adquirido na constância do casamento. Observância da súmula 377 do STF. Meação. Aplicação correta. SENTENÇA MANTIDA. $\mathrm{O}$ cônjuge virago faz jus à meação do patrimônio adquirido na constância do casamento, independente da prova de esforço comum, bastando a contribuição indireta, própria da vida de casado, inteligência da súmula 377 do STF” (e-STJ, fl. 99). (STJ, REsp 1.095.588, Relator: Raul Araújo, J. 07/10/2015).

20 Consigne-se a pertinente crítica de Ana Luiza Maia Nevares: “[...] claramente, o legislador graduar a tutela sucessória do cônjuge, ao menos em concorrência com os descendentes, conforme 
A sucessão do companheiro, por outro lado, desafia o princípio de que maior será a tutela sucessória quanto menor for a tutela do regime de bens, pois defere-lhe participação sobre os bens adquiridos onerosamente no curso da união estável, ou seja, sobre aqueles em que, em princípio, incide a meação. Por outro lado, quando o companheiro falecido somente houver deixado bens particulares, nada caberia ao companheiro sobrevivente.

Não bastasse, segundo o Código Civil vigente, não é reservado ao companheiro o direito real de habitação, tampouco ele é considerado herdeiro necessário.

\section{EFEITOS DO JULGAMENTO DO SUPREMO TRIBUNAL FEDERAL}

Por muito tempo o casamento representou a única forma de constituição da família considerada, então, legítima. Outras formas de relacionamento afetivo não baseadas no ato solene do casamento eram consideradas famílias ilegítimas, não merecedoras de tutela estatal.

Com a pluralidade familiar contemplada pela Constituição Federal de 1988, passou-se a admitir outras formas igualmente tuteláveis de família que não estavam nucleadas no casamento:

entre as entidades familiares não há hierarquia, já que todas desempenham a mesma função, qual seja, promover o desenvolvimento da pessoa de seus membros, devendo haver igualdade diante da proteção estatal, uma vez que a tutela da dignidade da pessoa humana é igual para todos e não se poderia tutelar mais ou menos uma pessoa pelo simples fato de integrar famílias diversas. ${ }^{21}$

o regime de bens [...]. No entanto, o Código Civil não alcançou bem o seu objetivo, porque, ao se valer dos regimes de bens abstratamente, descuidou do que ocorre em cada casamento, como resultado de suas respectivas relaçôes patrimoniais. Isso porque pode haver um regime de comunhão universal de bens sem meação - quando todos os bens do consorte são gravados com cláusula de inalienabilidade - e regime de separação de bens com patrimônio comum, adquirido em condomínio entre os consortes. Por essa razão, o legislador deveria ter se valido de critérios concretos, como exemplo, a existência ou não de bens comuns, como fazia o projeto primitivo do Código Civil de 1916, que admitia a concorrência do cônjuge com os descendentes, sempre que o regime matrimonial não lhe desse direito à meação de todos os bens do casal ou dos adquiridos na constância do casamento" (NEVARES, Ana Luiza Maia. Como preservar a isonomia das entidades familiares na sucessão legal? In: TEPEDINO, Gustavo; TEIXEIRA, Ana Carolina Brochado; ALMEIDA, Vítor (Coord.). Da dogmática à efetividade do Direito Civil: Anais do Congresso Internacional de Direito Civil Constitucional - IV Congresso do IBDCIVIL. Belo Horizonte: Fórum, 2017, p. 243-244).

21 NEVARES, Ana Luiza Maia. Casamento ou Uniāo Estável? Revista Brasileira de Direito Civil - RBDCIVIL, v. 8, abr./jun. 2016, p. 166-169. 
Considerando a função da família, o STF posicionou-se no sentido de que o sistema civil era mais eficiente na tutela do cônjuge sobrevivente e não haveria razão para que proteção semelhante não fosse dispensada à união estável, uma vez que se trata de entidades familiares sem distinção hierárquica entre elas. Em seu voto, no julgamento do RE 878.694, o Ministro Luís Roberto Barroso asseverou que "se o legislador civil entendeu que o regime previsto no art. 1.829 do CC/2002 é aquele que melhor permite ao cônjuge viver sua vida de forma digna após o óbito de seu parceiro, não poderia, de forma alguma, estabelecer regime diverso e menos protetivo para o companheiro".

Constou também no voto do Ministro Barroso no RE 878.694 do STF que a declaração de inconstitucionalidade do art. 1.790 do Código Civil implicaria lacuna no ordenamento jurídico pátrio que deveria ser suprida pela aplicação às uniôes estáveis do regramento sucessório previsto no art. 1.829 do Código Civil, o que foi seguido pela maioria dos Ministros:

Considerando-se, então, que não há espaço legítimo para que o legislador infraconstitucional estabeleça regimes sucessórios distintos entre cônjuges e companheiros, chega-se à conclusão de que a lacuna criada com a declaração de inconstitucionalidade do art. 1.790 do CC/2002 deve ser preenchida com a aplicação do regramento previsto no art. 1.829 do CC/2002, e não daquele estabelecido nas leis revogadas. Logo, tanto a sucessão de cônjuges como a sucessão de companheiros devem seguir, a partir da decisão desta Corte, o regime atualmente traçado no art. 1.829 do CC/2002.

Convém esclarecer que o emblemático julgamento do STF não equiparou os regimes sucessórios do cônjuge e do companheiro por unanimidade, havendo votos divergentes dos Ministros Dias Toffoli, Marco Aurélio e Ricardo Lewandowski. Em seu voto-vista, o Ministro Dias Toffoli ressaltou que união estável e casamento são modos distintos de constituição de família e que se deveria respeitar a autonomia do indivíduo de optar por aquela que melhor atende a seus anseios pessoais:

As entidades familiares são distintas, como especificado na Constituição Federal.

O casamento, portanto, não é união estável, o que autoriza que seus respectivos regimes jurídicos sejam distintos. Portanto, há de ser respeitada a opção feita pelos indivíduos que decIdem por se submeter a um ou a outro regime. Há que se garantir, portanto, os direitos fundamentais à liberdade dos integrantes da entidade de formar sua família por meio do casamento ou da livre convivência, bem como o respeito à autonomia de vontade para que os efeitos jurídicos de sua escolha sejam efetivamente cumpridos. 
Além disso, o Ministro Dias Toffoli mencionou em seu voto que a gratuidade do casamento assegurada pela Constituição Federal e pelo Código Civil reforça a liberdade pessoal em optar por uma ou outra modalidade de família.

A divergência, portanto, pautou-se, de um lado, na necessidade de se assegurar a tutela do companheiro sobrevivente nos mesmos moldes e no mesmo patamar protetivo assegurado pela lei ao cônjuge sobrevivente, e, de outro, na manutenção de um sistema regulamentador deliberadamente distinto das diferentes modalidades de família, que permitisse à pessoa que deseja viver em situação de conjugalidade a escolha consciente do regime que mais the aprouvesse.

Diante da prevalência da tese de inconstitucionalidade do art. 1.790 do Código Civil no Supremo Tribunal Federal, indaga-se qual a extensão da autonomia privada para a regulamentação de interesses emanados das relações familiares, conforme os parâmetros da legalidade constitucional.

\subsection{ESCOLHA DO MODELO JURÍDICO DE FAMÍLIA}

A relevância da liberdade na constituição da família foi apontada por Rodrigo da Cunha Pereira na identificação do paradoxo da equiparação entre união estável e casamento:

As tentativas de equiparação da união estável esbarram em contradiçôes. É que sua essência, seu cerne, é exatamente não querer intervenção excessiva do Estado. Isto é o que acontece na maioria dos países europeus, ou seja, o instituto da união estável escapa e escapará sempre às imposições e às tentativas de regramentos/equiparações. É o espaço do não institucionalizado e, pela sua natureza, é algo que quer exatamente fugir das regras e escapar dos limites e formalidades do casamento civil. Escolher viver em união estável está diretamente ligado à opção e desejo de um outro tipo de conjugalidade, fora daquele preestabelecido pelo Estado, ou uma forma alternativa ao casamento $^{22}$.

Ou seja, equiparar a união estável ao casamento a ponto de torná-los sinônimos invariavelmente tem por efeito extinguir as especificidades de cada um, fundindo-os em um conceito único. Sob a ótica de Rodrigo da Cunha Pereira, a união estável passa a ser absorvida pelo casamento, enquanto, para Renata Multedo e Maria Celina Bodin de Moraes, é o casamento que vem sofrendo constante desregulamentação estatal, como a desburocratização do divórcio por

22 PEREIRA, Rodrigo da Cunha. União Estável e Casamento: o paradoxo da equiparação. Disponível em: <http://www.rodrigodacunha.adv. br/uniao-estavel-e-casamento-o-paradoxo-da-equiparacao/>. Acesso em: 28 abr. 2018. 
meio da via extrajudicial ${ }^{23}$, aproximando-se da informalidade própria da união estável.

Sob um ou outro ângulo, parece ressaltar-se uma nova dinâmica de relacionamentos conjugais no seio da família, em que o papel interventor do Estado é colocado à prova. A família quer se submeter às normas cogentes ou o desejo é pela liberdade de se autorregulamentar?

Cabe salientar, nesse aspecto, o direcionamento convergente das interações intersubjetivas no seio familiar para a concretização dos princípios da dignidade humana e da solidariedade social. A família, seja instituída pelo casamento, seja pela união estável, carrega consigo a função de promover o livre desenvolvimento da personalidade de cada um de seus membros, por meio da formação de uma rede de solidariedade:

A Constituição e o direito de família brasileiros são integrados pela onipresença dos dois princípios fundamentais estruturantes: a dignidade da pessoa humana e a solidariedade. A solidariedade e a dignidade são os dois hemisférios indissociáveis do núcleo essencial irredutível da organização social, política e cultural e do ordenamento jurídico brasileiros. De um lado, o valor da pessoa humana enquanto tal, e os deveres de todos para com sua realização existencial, nomeadamente do grupo familiar; de outro lado, os deveres de cada pessoa humana com as demais, na construção harmônica de suas dignidades ${ }^{24}$.

Por essa razão, afirma-se que apesar de estruturalmente casamento e união estável se distinguirem em sua formação, funcionalmente ambos são idênticos, pois exercem o papel de constituição de famílias ${ }^{25}$, portanto, servem à instituição da solidariedade familiar entre seus membros.

23 'E aqui é o caso de indagar-se: estaria mesmo a jurisprudência 'sepultando' a união estável, como normalmente se pensa? Não seria o caso de pesquisar se o que vem sendo atingido é o casamento? Parece que a segunda formulação possa corresponder melhor à visão prospectiva dos fenômenos, considerando, especialmente, o enorme número de regras a serem cumpridas para o casar e o descasar e a ausência completa delas para viver em união estável, obtendo-se em ambos os casos, como vimos, praticamente os mesmos efeitos" (MULTEDO, Renata Vilela; BODIN DE MORAES, Maria Celina. A privatização do casamento. Civilistica.com. Rio deJaneiro,a.5,n.2,2016. Disponívelem:<http://civilistica.com/a-privatizacao-do-casamento/>. Acesso em: 28 abr. 2018).

24 LÔBO, Paulo. Princípio da solidariedade familiar. Disponível em: <http://www.ibdfam.org. br/_img/congressos/anais/78.pdf> Acesso em: 28 abr. 2018.

25 “A diferença entre casamento e união estável está no modo pelo qual se constituem. Estruturalmente são institutos diversos, já que o casamento é um ato formal, solene e público, enquanto a união estável é informal. Funcionalmente, no entanto, ambos são idênticos, já que se destinam a constituir família, que é a base da sociedade e tem especial proteção do Estado, 
Permanece ainda a indagação: é desejável tornar sinônimos o casamento e a união estável quanto aos efeitos jurídicos projetados por cada fenômeno?

Em termos sucessórios, a decisão do STF corrigiu graves distorções quanto ao tratamento jurídico do companheiro sobrevivente ao considerar inconstitucional a disciplina do art. 1.790 do Código Civil, pois o legislador havia considerado a união estável como merecedora de menos direitos, a ponto de privilegiar colaterais do falecido, o que, como já exposto, não se coaduna com a realidade social atual.

Como bem observa Rodrigo da Cunha Pereira, contudo, compreender os institutos jurídicos do casamento e da união estável como formas distintas de constituição de família não significa hierarquizá-los, ou reservar a tutela jurídica a apenas um deles, historicamente, no caso, ao casamento, relegando a união estável à marginalidade, mas talvez apenas reconhecer maior extensão de liberdade nas unióes não formais do que naquelas que dependem de um ato solene - aliás, dos mais solenes do direito civil:

Não podemos confundir, entretanto, a não equiparação das uniōes estáveis com o casamento com a não proteção do Estado a este tipo de união, seu reconhecimento enquanto forma de família e como instituto que tem consequências jurídicas. União estável, ou união livre, como o próprio nome indica, é aquela livre de regulamentação, registros e controles oficiais. Equipará-las ao casamento significa interferir na liberdade de escolher a forma de se constituir família. Essa tendência é, na verdade, uma posição moralista e equivocada, pois seria o mesmo que não aceitá-la como uma forma de família diferente do casamento. É como se fosse para resgatá-la de algo que não é correto, como moralistamente estabeleceu-se no artigo da Constituição da República $\left(226, \$ 3^{\circ}\right)$ que o Estado facilitará sua conversão em casamento.

Em síntese, é bem-vinda a tutela patrimonial do companheiro por meio da intervenção estatal que garanta, na ausência de convenção entre as partes, os direitos que são assegurados aos cônjuges; no entanto, essa tutela não pode acarretar excesso de paternalismo ${ }^{26}$, despojando as partes de autonomia privada para a autorregulamentação de seus interesses de modo diverso, caso assim desejem.

Portanto, o recrudescimento da regulamentação estatal sobre a união estável somente se justifica se representar apenas uma fixação de "regras-padrão", ou seja, de normas dispositivas a partir do que se considera justo para o casamento e que

direcionada à pessoa de cada um de seus membros, promovendo a dignidade de seus componentes" (NEVARES, Ana Luiza Maia. Casamento ou União Estável? Revista Brasileira de Direito Civil-RBDCIVIL, vol. 8, abr./jun. 2016, p. 250).

26 Cf. MUlTEDO, Renata Vilela; BODIN DE MORAES, Maria Celina. A privatização do casamento. Civilistica.com. Rio de Janeiro, a. 5, n. 2, 2016. Disponível em: <http://civilistica. com/a-privatizacao-do-casamento/>. Acesso em: 28 abr. 2018. 
possam ser aderidas ou modificadas pelas partes que assim desejarem, conferindo-se um espaço mínimo de liberdade para que se decida a dinâmica da solidariedade familiar de acordo com suas necessidades peculiares ${ }^{27}$. Ou, ainda, caso a intervenção estatal na família volte-se para a tutela dos interesses das pessoas em situação de vulnerabilidade ${ }^{28}$.

\subsection{LIBERDADE NO ÂMBITO SUCESSÓRIO}

Antes mesmo do julgamento em Repercussão Geral que declarou incidentalmente a inconstitucionalidade do art. 1.790 do Código Civil, abalizada doutrina propugnava a pertinência de se considerar companheiros como herdeiros necessá$\operatorname{rios}^{29-30}$, como forma de garantir a intangibilidade da legítima também às uniōes estáveis ${ }^{31-32}$.

27 A exemplo, Ana Luiza Maia Nevares afirma: "Não raro são os casos em que casais, em especial quando em segundas núpcias pretendem deixar todo o seu patrimônio para os seus filhos exclusivos, porque o consorte é independente financeiramente, sendo esta a vontade compartilhada por ambos os partícipes da relação, sendo, ainda, muito comum a frustração diante do fato de que a sucessão do cônjuge acarretará a transferência de patrimônios de famílias para pessoas diversas, porque herdeiros só do supérstite" (NEVARES, Ana Luiza Maia. Como preservar a isonomia das entidades familiares na sucessão legal? In: Tepedino, Gustavo; TEIXEIRA, Ana Carolina Brochado; ALMEIDA, Vítor (Coord.). Da dogmática à efetividade do direito civil: Anais do Congresso Internacional de Direito Civil Constitucional - IV Congresso do IBDCIVIL. Belo Horizonte: Fórum, 2017, p. 243.)

28 "Vale sublinhar que a desejada redução da intervenção estatal não significa recusar hipóteses em que o Estado deva desempenhar um papel ativo de ingerência na seara da família. Tais casos, como se viu, são os que envolvem sujeitos vulneráveis, como idosos e crianças, violência doméstica no âmbito familiar, dentre outros. Nessas hipóteses, justifica-se plenamente que a liberdade consubstanciada na autonomia privada ceda espaço à incidência de imposiçôes próprias da solidariedade familiar" (Multedo, Renata Vilela; BODIN DE MORAES, Maria Celina. A privatização do casamento. Civilistica.com. Rio de Janeiro, a. 5, n. 2, 2016. Disponível em: <http://civilistica.com/a-privatizacao-do-casamento/>. Acesso em: 28 abr. 2018.)

29 Cf. TEPEDINO, Gustavo. Controvérsias sobre a sucessão do cônjuge e do companheiro. Pensar, Fortaleza, v. 17, n. 1, p. 138-160, jan./jun. 2012.

30 "Apesar dessas benéficas modificaçōes a favor do cônjuge - que detém, agora, também a qualidade de herdeiro necessário -, é certo que o legislador perdeu excelente oportunidade de descrever proteção, expressamente, também a favor do convivente supérstite. Aliás, se o legislador já lhe havia garantido, por força do art. 1.790 do CC, a concorrência com os filhos do falecido (e, na falta destes, com os seus ascendentes; e, por fim, na falta de ambos, o recolhimento do total da herança), não teria sido demasiado esperar que lhe conferisse, também, a condição de herdeiro necessário. Essa 'ordem de vocação', especial para as hipóteses de abertura da sucessão no decorrer de união estável, em alguns aspectos assemelha-se à ordem de vocação do cônjuge supérstite, não se vislumbrando motivo para que as condições do cônjuge e do 
Após o julgamento do STF, é inarredável a aplicação do art. 1.829 do Código Civil, que trata da ordem de vocação hereditária na sucessão legítima, cuja leitura deve agora contemplar, ao lado dos cônjuges e no mesmo patamar, o companheiro. $\mathrm{Na}$ tese fixada, entretanto, não ficou expressamente consignada a aplicação à união estável do art. 1.845, que define o cônjuge entre os herdeiros necessários, embora o Ministro Edson Fachin tenha feito constado em seu voto que "deve-se aplicar a ambos os modelos de conjugalidade as mesmas regras, ou seja, aquelas do art. 1.829 e seguintes do Código Civil."

Indaga-se, portanto, se a equiparação sucessória entre cônjuges e companheiros deve estender-se à elevação do companheiro como herdeiro necessário, tal como o cônjuge, ou se limita ao posicionamento do companheiro na ordem de vocação hereditária.

Conforme já exposto, a realocação do companheiro na mesma posição que o cônjuge na ordem de vocação hereditária visou a retificar a injustiça no menoscabo dispensado historicamente à união estável, perceptível na forma como o Código Civil tratou o companheiro no art. 1.790.

Por outro lado, consignou-se também a importância de se preservar um mínimo de liberdade para a autorregulamentação de interesses decorrentes das situaçôes familiares em que as partes ocupem posição de igualdade, a fim de se evitar

convivente não se equiparassem também à proteção da legítima, como, aliás, seria de bom alvitre, diante das disposições constitucionais a respeito da equivalência entre o casamento e a união estável.” (HIRONAKA, Giselda Maria Fernandes Novaes. Morrer e Suceder: passado e presente da transmissão sucessória concorrente. 2 ed. São Paulo: RT, 2014, p. 354)

31 "Existe discussão na doutrina sobre o companheiro, se ele seria ou não herdeiro necessário, pois o artigo [art. 1.845, CC] foi categórico quanto aos descendentes, aos ascendentes e ao cônjuge. Entretanto, o art. 1.850 do CC só permite que o testador afaste os colaterais da sucessão, não mencionando a possibilidade de exclusão do companheiro sobrevivente. A melhor interpretação é a que privilegie o companheiro, por entender que a união estável é entidade familiar protegida constitucionalmente, conforme art. $226 \$ 3^{\circ}$." (TEIXEIRA, Daniele Chaves. A necessidade de revisitar o instituto da legítima. In: MORAES, Carlos Eduardo Guerra de; RIBEIRO, Ricardo Lodi (Coord.). Direito Civil. Rio de Janeiro: Freitas Bastos, 2015. Coleção Direito UERJ 80 anos, p. 395)

32 Em sentido contrário: "Os demais herdeiros, ou seja, os parentes colaterais do falecido e os companheiros são chamados de herdeiros facultativos, já que não têm direito à legítima. (...) Nesse sentido, determina o art. 1.850 do CC em vigor que 'para excluir da sucessão os herdeiros colaterais, basta que o testador disponha de seu patrimônio sem os contemplar'. A regra é inútil e incompleta. Inútil porque se os colaterais não são herdeiros necessários, por óbvio basta que o testador elabore testamento sem os contemplar para que eles automaticamente nada herdem. E incompleta porque se o companheiro também é herdeiro facultativo, deveria o dispositivo mencioná-lo em sua redação." (TARTUCE, Flávio; SIMÃO, José Fernando. Direito Civil. 4 ed. São Paulo: Método, 2011. v. 6, p. 291-292) 
o excesso de paternalismo, bem como de submeter as partes que deliberadamente pretendiam obedecer regramento mais flexível a se regerem pelas normas mais rígidas decorrentes da solenidade do casamento.

Nesse aspecto, portanto, não haveria incompatibilidade alguma em se entender pela literalidade do art. 1.845, excluída a união estável, pois seria uma forma não de desproteger o companheiro - visto que sua participação sucessória estaria assegurada nas mesmas classes previstas para o cônjuge na ordem de vocação hereditária -, mas de conferir liberdade, nesse tipo de união, para que haja disposição de vontade em sentido contrário, que possa adequar-se à necessidade de cada família. Estaria, assim, assegurado o cumprimento ao princípio da igualdade das modalidades de família, ao mesmo tempo que não se tolheria a liberdade dos membros da relação conjugal de dispor de seu patrimônio depois da morte conforme sua conveniência, não estando limitado pela legítima do companheiro.

Recentemente, na VIII Jornada de Direito Civil promovida pelo Conselho da Justiça Federal, foi aprovado enunciado com o seguinte teor:

A decisão do Supremo Tribunal Federal que declarou a inconstitucionalidade do art. 1.790 do Código Civil não importa equiparação absoluta entre o casamento e a união estável. Estendem-se à uniáo estável apenas as regras aplicáveis ao casamento que tenham por fundamento a solidariedade familiar. Por outro lado, é constitucional a distinção entre os regimes quando baseada na solenidade do ato jurídico que funda o casamento, ausente na união estável.

Nota-se que a doutrina concordante com essa posição pretendeu garantir a tutela do companheiro nas relações baseadas na solidariedade familiar, apesar de afastar a identidade entre o casamento e a união estável, com fundamento na solenidade do ato jurídico. Interpretação possível defendida neste trabalho é que essa solenidade se exprime também na extensão da liberdade de autorregramento das relações patrimoniais entre vivos e em decorrência da morte, assegurando-se a vocação hereditária nos mesmos termos que aquela dispensada ao cônjuge, no entanto, sem equipará-lo aos herdeiros necessários e, portanto, sem reserva da legítima ${ }^{33}$.

\section{CONCLUSÃO}

O julgamento do STF encerrou, parcialmente, a polêmica sobre os diferentes regimes sucessórios do cônjuge e do companheiro quando declarou a inconstitucionalidade do art. 1.790 e determinou, para o suprimento da lacuna, a aplicação do art. 1.829 do Código Civil.

33 Código Civil, art. 1.846. Pertence aos herdeiros necessários, de pleno direito, a metade dos bens da herança, constituindo a legítima. 
Não resta dúvida que é bem-vinda a substituição do regime sucessório do companheiro pelas regras aplicáveis aos cônjuges. De fato, tal discriminação era inconstitucional. Assim, quanto ao cerne da decisão do STF não há polêmica. $\mathrm{O}$ problema reside nos seus efeitos periféricos, a saber: a equiparação deve ser extensiva para todos os fins de direito? A decisão teria o condão de transmutar a posição do companheiro para herdeiro necessário?

Entende-se que a resposta a essas perguntas é não. $\mathrm{O}$ argumento para tanto é que o STF não se desonerou do ônus constitucional de fundamentação a ponto de dar um salto para alcançar tais consequências jurídicas. Ao analisar os votos, é nítido que esses pontos não foram fruto de debate intenso e por vezes nem sequer foram mencionados. Por isso, num futuro próximo, a resposta até poderá ser afirmativa, após o julgamento dos embargos de declaração. Mas a questão é que deverá necessariamente ocorrer o cumprimento do dever constitucional de fundamentação.

Tendo isso presente, o próximo passo seguindo essa linha de raciocínio é indagar se uma equiparação total, geral e irrestrita entre casamento e união estável é efetivamente desejável.

Dos argumentos que se extraem dos defensores da inconstitucionalidade, como o Relator Ministro Barroso, e dos defensores da constitucionalidade, como o Ministro Dias Toffoli, percebe-se que as divergências emergem da compreensão sobre as razões que levam um casal a manter uma união estável ou a se casar.

O Ministro Dias Toffoli mencionou em seu voto que a ausência de recursos financeiros não poderia ser uma justificativa para a opção pela união estável, pois a Constituição Federal e o Código Civil asseguram a gratuidade do casamento. Por outro lado, os dados do IBGE que apontam o aumento de uniões não formalizadas entre os anos de 2000 e 2010 também indicam que a maior parte dessas uniōes ocorre em camadas socialmente desfavorecidas.

Quando se analisa o percurso histórico do reconhecimento da união estável, desde o deferimento de indenização por serviços domésticos à companheira até as discussões atuais sobre a tutela patrimonial sucessória, nota-se algo em comum: a desigualdade de gênero entre o homem e a mulher e a necessidade de se proteger as pessoas, sobretudo as mulheres, que viviam em situação de companheirismo e que, após a separação ou a morte do companheiro, viam-se desamparadas pelo direito. Esse foi o ponto de partida do Ministro Barroso.

Contudo, o período hodierno também é permeado por outras realidades. E, nesse sentido, a aproximação dos modelos jurídicos do casamento e da união estável parece ameaçar a possibilidade de apresentar soluções plurais para realidades plurais. 
Nessa mesma linha de raciocínio, cabe questionar qual seria a real valia de termos dois institutos que ao ser paulatinamente equiparados se tornem verdadeiramente idênticos e sinônimos.

No fundo, é certo que a maior dificuldade em responder a indagação sobre se é desejável a equiparação integral do regime sucessório da união estável ao casamento reside no fato de serem inúmeras as razões pelas quais as pessoas optam por cada um dos institutos. Se por um lado alguns pares estão em união estável porque estão dentro de um cenário de vulnerabilidade e necessitam de proteção, por outro temos casais que estão vivendo relações paritárias e precisam de instrumentos jurídicos que confiram mais flexibilidade e liberdade para que possam decidir o destino de seus patrimônios.

Em outras palavras, percebe-se uma tensão entre a concomitância de casais que esperam do Estado um papel paternalista e protetor e de outros que desejam espaço livre para que eles próprios possam desenhar a realidade que desejam (respeitadas molduras gerais da lei). Com isso dito, fica clara uma conclusão: a de que o Estado brasileiro se equivoca no momento atual, quando trata realidades distintas da mesma e exata forma.

\section{REFERÊNCIAS}

HIRONAKA, Giselda Maria Fernandes Novaes. Morrer e suceder: passado e presente da transmissão sucessória concorrente. 2. ed. São Paulo: RT, 2014.

LÔBO, Paulo. Princípio da solidariedade familiar. Disponível em: <http://www. ibdfam. org.br/_img/congressos/anais/78.pdf> Acesso em: 28 abr. 2018.

MULTEDO, Renata Vilela; BODIN DE MORAES, Maria Celina. A privatização do casamento. Civilistica.com. Rio de Janeiro, a. 5, n. 2, 2016. Disponível em: <http://civilistica.com/a-privatizacao-do-casamento/>. Acesso em: 28 abr. 2018.

NEVARES, Ana Luiza Maia. Casamento ou união estável? Revista Brasileira de Direito Civil-RBDCIVIL, vol. 8, abr./jun. 2016, p. 166-169.

NEVARES, Ana Luiza Maia. Como preservar a isonomia das entidades familiares na sucessão legal? In: TEPEDINO, Gustavo; TEIXEIRA, Ana Carolina Brochado; ALMEIDA, Vítor (Coord.). Da dogmática à efetividade do Direito Civil: Anais do Congresso Internacional de Direito Civil Constitucional - IV Congresso do IBDCIVIL. Belo Horizonte: Fórum, 2017, p. 239-252.

PEREIRA, Rodrigo da Cunha. União estável e casamento: o paradoxo da equiparação. Disponível em: <http://www.rodrigodacunha.adv. br/uniao-estavel-e-casamento-o-paradoxo-da-equiparacao/>. Acesso em: 28 abr. 2018.

TARTUCE, Flávio; SIMÃO, José Fernando. Direito civil. 4. ed. São Paulo: Método, 2011. v. 6. 
•• Direito Civil: Estudos | Coletânea do XV Encontro dos Grupos de Pesquisa - IBDCivil

TEIXEIRA, Daniele Chaves. A necessidade de revisitar o instituto da legítima. In: MORAES, Carlos Eduardo Guerra de; RIBEIRO, Ricardo Lodi (Coord.). Direito civil. Rio de Janeiro: Freitas Bastos, 2015. Coleção Direito UERJ 80 anos.

TEPEDINO, Gustavo. Controvérsias sobre a sucessão do cônjuge e do companheiro. Pensar, Fortaleza, v. 17, n. 1, p. 138-160, jan./jun. 2012.

VELOSO, Zeno. Direito sucessório dos companheiros. III Congresso Brasileiro de Direito de Familia. Disponível em: <http://www.ibdfam.org.br/_img/congressos anais/188.pdf>. Acesso em: 27 abr. 2018. 